\title{
A comparative study of the physical properties of conventional and Grander-modified adhesive systems
}

\section{Estudo comparativo das propriedades físicas de sistemas adesivos convencional e Grander-modificado}

\begin{abstract}
Purpose: The objective of this study was to evaluate the influence of the Grander technology in reducing the surface tension and contact angle of a self-etch adhesive system.

Methods: Distilled water and Xeno III self-etch adhesive system (Dentsply) were modified by physical contact with the Flexible unit Grander system to revitalize water, for 48 hours, resulting in four groups: Group 1 - Xeno III under normal conditions; Group 2 - Xeno III modified by Grander; Group 3 - distilled water under normal conditions; Group 4 - distilled water system modified by the Grander system; Surface tension and contact angle (dentin substrate and titanium plate) of the adhesive system and water in normal and Grander-modified conditions was measured with a goniometer. Data were analyzed by ANOVA and Tukey test (5\%).

Results: Grander technology reduced the surface tension of water but not of the adhesive system Xeno III. The contact angle property of the adhesive ystem was not affected.

Conclusion: Grander technology did not interfere with the surface tension and contact angle physical properties of the Xeno III self-etch adhesive system.
\end{abstract}

Key words: Dentin; surface tension

\section{Resumo}

Objetivo: Esta pesquisa verificou os efeitos da tecnologia Grander na alteração da tensão superficial e ângulo de contato de um sistema adesivo autocondicionante.

Metodologia: O sistema adesivo autocondicionante Xeno III (Dentsply) e a água destilada foram modificados pelo contato físico com a unidade flexible do sistema Grander para revitalização de águas por 48 horas, resultando em 4 grupos: Grupo 1 - sistema adesivo Xeno III em condições de normalidade; Grupo 2 - sistema adesivo Xeno III modificado pelo sistema Grander; Grupo 3 - água destilada em condições de normalidade; Grupo 4 - água destilada modificada pelo sistema Grander. A tensão superficial dos líquidos foi verificada em goniômetro utilizando cinco medidas para cada gota de líquido. O ângulo de contato foi medido com o goniômetro sobre os substratos placa de titânio e dentes bovinos. Os dados foram submetidos aos testes ANOVA e Tukey (5\%).

Resultados: Houve redução significativa da tensão superficial da água com a modificação pelo sistema Grander. Não houve redução da tensão superficial e ângulo de contato para o sistema adesivo Xeno III.

Conclusão: A tecnologia Grander não interferiu com a tensão superficial e o ângulo de contato para o sistema adesivo Xeno III.

Palavras-chave: Dentina; tensão superficial

\author{
Sérgio Eduardo de Paiva Gonçalves a \\ Rafael Augusto Burim a \\ Patrícia Rondon Pleffken a \\ Daphne Câmara Barcellos" \\ Ana Paula Martins Gomes a \\ Maria Filomena Rocha Lima Huhtala a
}

- São José dos Campos School of Dentistry, UNESP
- São Paulo State University, São José dos Campos, - São Paul Brazil

Correspondence:

Correspondence:
Sérgio Eduardo de Paiva Gonçalves.

Avenida Engenheiro Francisco José Longo, 777, Jardim São Dimas

São José dos Campos, SP - Brazil

12245-000

E-mail: sergio@fosjc.unesp.br

Received: April 5, 2010

Accepted: October 16, 2011

Conflict of Interests: The authors state that there are no financial and personal conflicts of interest that could have inappropriately influenced their work.

Copyright: (c) 2011 Gonçalves et al.; licensee EDIPUCRS. This is an Open Access article distributed under the terms of the Creative Commons AttributionNoncommercial-No Derivative Works 3.0 Unported License. 


\section{Introduction}

Bonding to dental substrates is frequently studied in dentistry. Although the adhesion to enamel by the acid etching technique proposed by Buonocore (1) has proven safe and effective, bonding to dentin still presents a challenge due it its complex structure (2).

Dentin is composed of $18 \%$ organic matrix (collagen type I), $12 \%$ water and $70 \%$ inorganic matrix (hydroxyapatite crystals) $(3,4)$. When this tissue is instrumented, a smear layer is formed, which is comprised of the mineral particles, collagen, blood, saliva and bacteria (3-9). The smear layer is deposited on the dentin surface, blocking the dentinal tubules and acting as a natural barrier of low permeability $(5,10)$. Thus, several adhesives promote treating the smear layer in order to increase dentin bonding.

Total-etch adhesives remove the smear layer by acid etching, providing the complete removal of the smear layer and smear plugs, followed by demineralization of the dentin surface, resulting in a collagen network with low mineral content (3). Thus, the primer and bonding agent are able to penetrate the collagen network (intertubular and peritubular dentin) and produce a hybrid layer $(3,10)$.

Following the modern trend of simplifying the clinical steps and saving operating time, new bonding strategies have been developed. Watanabe (11) proposed the use of high concentrations of acidic resinous monomers which, in an aqueous solution, are capable of releasing $\mathrm{H}+$ ions and producing etching of the dental structure, while also penetrating into the substrate. These materials were called self-etching, since they dispensed of the separate application of acid etching.

The penetration of a material is influenced by the properties of that material and the substrate. Surface tension and viscosity are properties that influence penetration $(12,13)$. When a liquid touches a solid, an angle is formed between the solid and the interface tangent of the air-liquid, which is called a contact angle (12). Contact angles vary with the surface state, surface tension, surface energy of the solid and the level of interaction between the liquid and solid (12). Reduction in surface tension and contact angle of adhesives increase their wetting capacity and ensure a greater diffusibility (14).

Recently, Johan Grander developed the Grander technology, a method that revitalizes water by the physical spatial restructuring of its molecules. This restructuring allows a molecular balance with improved transportation properties, most likely by reducing its surface tension (15).

By extrapolating the water revitalization process for the ideal conditions desired in terms of adhesiveness, an adhesive system could be modified, as it is a liquid with an aqueous solvent, to provide a reduction in surface tension and contact angle, increasing its wetting capacity and ensuring greater diffusibility.

As the reduction in surface tension is directly related to the penetration of a liquid, and extrapolating the water revitalization process for the ideal conditions desired in terms of adhesiveness, the objective of this study was to evaluate the influence of the Grander Technology on the surface tension and contact angle of a self-etch adhesive system. The null hypothesis tested was that the Grander Technology does not change the surface tension and contact angle properties of an adhesive system.

\section{Material and Methods}

\section{Modification of an adhesive system and water using the Grander System}

The first step required for the current study was the modification of the Xeno III self-etch adhesive system (Dentsply De Trey GmbH D, Konstanz, Germany) and water by using the Grander System:

- Experimental: Two sets of the same batch of the adhesive system were used. One set was kept unchanged and the other was placed in physical contact with the Grander System Flexible Unit (Grander Technologies, Jochberg, Austria). This system consists of a device named "Flexible Unit", capable of revitalizing water using electromagnetic induction to rearrange molecules through contact with bottles of liquids or by the passage of liquids through the interior of the channels placed among cylinders that build the core of the unit. Thus, the bottles of the adhesive system were placed in contact with the unit flexible for $48 \mathrm{~h}$.

- Control: Two bottles with $5 \mathrm{~mL}$ of distilled water were revitalized by the grander system for $48 \mathrm{~h}$, following the same treatments described above.

The commercial name, chemical composition, batch number and manufacturer of the material used are presented in Table 1.

Table 1. Commercial name, composition and manufacturer of the material used.

\begin{tabular}{|c|c|c|}
\hline Commercial name & Composition & Manufacturer \\
\hline $\begin{array}{l}\text { Xeno III self-etch adhesive } \\
\text { system }\end{array}$ & $\begin{array}{l}\text { Agent A: HEMA, Ethanol, Amorphous } \\
\text { silica, purified water, and THB (Tolvene } \\
\text { hydroxybutylate). } \\
\text { Agent B: Methacrylic functionalized with } \\
\text { phosphoric acid (Piro-EMA); Mono fluoro } \\
\text { phosphazene modified (PEM-F) of urethane } \\
\text { dimethacrylate; THB; Camphorquinone and } \\
\text { Ethyl-4-dimethylamino - Benzoate. }\end{array}$ & $\begin{array}{l}\text { Dentsply De Trey GmbH, } \\
\text { Konstanz, Germany }\end{array}$ \\
\hline Distilled water & Purified water without ions & CINORD, Serrana, SP, Brazil \\
\hline
\end{tabular}




\section{Surface tension measurement}

For surface tension measurements, four groups were established:

- Group 1 - distilled water (control);

- Group 2 - Grander-modified distilled water (experimental);

- Group 3 -Xeno III self-etch adhesive system (control);

- Group 4 - Grander-modified Xeno III self-etch adhesive system (experimental).

The surface tension of each group was measured using an automatic goniometer (Ramé-Hart Instrument Co. 0.100-00, Washington DC, USA). Temperature and moisture conditions of the environment were maintained at $23^{\circ} \mathrm{C}$ and $50 \%$, respectively.

Samples were collected from each group using a microsyringe (Gilmont, Barrington, Illinois, USA). The microsyringe is a Teflon micrometer with a glass barrel, a rubber sealing ring and a number 22 metallic needle. The barrel was wrapped in aluminum foil in order to prevent the adhesive systems from polymerizing due to the room light. The whole assembly was fixed in the goniometer support to measure the surface tension.

By turning the micrometer screw clockwise by hand, a gradual drop of liquid was obtained, which remained attached to the needle tip due to its surface tension. The device allows for the adjustment of the number of steps/time. Twenty measures were taken for every drop of each liquid tested, yielding an average of surface tension.

Data were submitted to two-way ANOVA (factors: liquid and procedure) and the Tukey test, both at a 5\% level of significance.

\section{Contact angle measurement}

For contact angle measurement, two groups were established:

- Group 1 - Xeno III self-etch adhesive system (control);

- Group 2 - Grander-modified Xeno III self-etch adhesive system (experimental).

The contact angle was evaluated using two different substrates: a titanium plate and enamel substrate.

- Contact angle measurement on the titanium plate: Twenty drops of the Xeno III adhesive system were dropped individually on a titanium plate. A waiting time of $20 \mathrm{~s}$ was standardized to stabalize the image at the time that the drop contacted the surface of the titanium plate. The contact angle was measured using an automatic goniometer (Ramé-Hart Instrument Co. 0.100-00, Washington DC, USA). Temperature and moisture conditions of the environment were stabilized at $23^{\circ} \mathrm{C}$ and $50 \%$, respectively. For each drop, twenty measurements were performed and the mean values were calculated. The titanium plate was used primarily because it is inert; therefore, drop scattering is bound only to the properties of the liquid dripped, without influencing the substrate.
- Contact angle measurement on the dentin substrate: Forty extracted bovine incisors were cleaned and stored in distilled and deionized water in a freezer at $-18^{\circ} \mathrm{C}$ until use. The roots were sectioned using a steel diamond disc (KG Sorensen, Rio de Janeiro, Brazil) at the cementenamel junction. The buccal surfaces were worn using abrasive papers (granulations 400 and 600) coupled to a circular polishing machine (PA-10, Panambra, São Paulo, Brazil) under water cooling, to expose a dentin area of $3 X 3 \mathrm{~mm}$. An opening was made on the lingual side using a 1012 spherical diamond tip (KG Sorensen, Rio de Janeiro, RJ, Brazil) to remove the pulpal tissue and to allow the amount of remaining dentin to be measured. The remaining dentin thickness was standardized at $2 \mathrm{~mm}$ by grinding the dental surface and using a caliper (Golgran, São Caetano do Sul, Brazil) to measure the thickness. The openings on the lingual face and root canal were clogged with utility wax (Polidental, Cotia, SP, Brazil). The ground buccal surfaces were placed face down in a silicone mold, which was then filled with self polymerizing acrylic resin (Classic, São Paulo, Brazil). The dentin surface was standardized using abrasive papers (granulations of 1200 and 4000) for $20 \mathrm{~s}$ each, coupled to a circular polishing machine. Each specimen received one drop of Xeno III adhesive system on the dentin surface, for a total of twenty drops for each group (experimental and control). The contact angle was measured by the same protocols as described above. For each drop, twenty measurements were performed and the mean values were calculated.

The contact angle data were submitted to a two-way ANOVA (factors: substrate and procedure) followed by the Tukey test, both at a $5 \%$ level of significance.

\section{Results}

\section{Surface tension}

Table 2 shows the results of the ANOVA test. For the liquid factor, ANOVA showed a $P=0.0001 \quad(\mathrm{~F}=3240.63)$, with 1 degree of freedom. ANOVA presented a $P=0.23$ $(\mathrm{F}=1.55)$, with 1 degree of freedom, for the procedure factor. The ANOVA showed a $P=0.0098(\mathrm{~F}=8.58)$, with 1 degree of freedom, for the interaction between factors. The liquid factor and interaction between the liquid and procedure factors showed significant differences between groups.

Table 2. ANOVA's test results for surface tension.

\begin{tabular}{lccc}
\hline \multicolumn{1}{c}{ Factor } & $\begin{array}{c}\text { Degree of } \\
\text { freedom }\end{array}$ & $\mathbf{F}$ & $\boldsymbol{P}$ \\
\hline Procedure & 1 & 1.55 & 0.2307 \\
Liquid & 1 & 3240.63 & $0.0001^{*}$ \\
Interaction & 1 & 8.58 & $0.0098^{*}$ \\
\hline
\end{tabular}

$* P<0.05$ 
Table 3 shows the results of Tukey's test for the liquid factor. Distilled water showed that the surface tension reduced significantly when compared to the Xeno III adhesive system.

Table 4 shows the results of Tukey's test for the interaction between factors. Distilled water modified by the Grander System (Experimental group) showed a significant reduction in surface tension when compared to distilled water of the control group.

Table 3. Tukey's test results for liquid factor (D/cm).

\begin{tabular}{lcc}
\hline \multicolumn{1}{c}{ Liquid } & Mean $(\mathrm{D} / \mathrm{cm})$ & Homogeneous sets* \\
\hline Distilled water & 70.931 & $\mathrm{~A}$ \\
Adhesive system & 30.580 & $\mathrm{~B}$ \\
\hline * The groups followed by the same letters showed no significant \\
$\begin{array}{l}\text { differences. } \\
\text { The }\end{array}$
\end{tabular}

Table 4. Tukey's test results for interaction between the factors (D/cm).

\begin{tabular}{llcc}
\hline \multicolumn{1}{c}{ Procedure } & \multicolumn{1}{c}{ Liquid } & $\begin{array}{c}\text { Mean } \\
(\mathrm{D} / \mathrm{cm})\end{array}$ & $\begin{array}{c}\text { Homogeneous } \\
\text { sets* }\end{array}$ \\
\hline Control & Distilled water & 72.411 & $\mathrm{~A}$ \\
Grander-modified & Distilled water & 69.452 & $\mathrm{~B}$ \\
Grander-modified & Adhesive system & 31.177 & $\mathrm{C}$ \\
Control & Adhesive system & 29.984 & $\mathrm{C}$ \\
\hline
\end{tabular}

* The groups accompanied by the same letters presented no significant differences.

\section{Contact angle}

Table 5 shows the results of the ANOVA test. For the procedure factor, ANOVA showed a $P=0.4049(\mathrm{~F}=0.71)$, with 1 degree of freedom. The ANOVA indicated a $P=0.8781$ $(\mathrm{F}=0.02)$, with 1 degree of freedom, for the substrate factor. The ANOVA showed a $P=0.8269(\mathrm{~F}=0.05)$, with 1 degree of freedom, for the interaction between factors. The results showed an absence of significant differences between groups.

Table 5. ANOVA's test results for contact angle.

\begin{tabular}{lccc}
\hline \multicolumn{1}{c}{ Factor } & $\begin{array}{c}\text { Degree of } \\
\text { freedom }\end{array}$ & $\mathbf{F}$ & $\boldsymbol{P}$ \\
\hline Procedure & 1 & 0.71 & 0.4049 \\
Substrate & 1 & 0.02 & 0.8781 \\
Interaction & 1 & 0.05 & 0.8269 \\
\hline
\end{tabular}

\section{Discusion}

There are two ways to improve adhesion to dentin: impregnation of the monomer into the substrate and increasing the diffusivity of the monomer into the substrate (17). Therefore, the surface tension of the adhesive should be as low as possible (13).
The present study evaluated a new proposal to reduce the surface tension and increase diffusivity of adhesives. This technique is based on research by Johan Grander, the Grander technology, a method that revitalizes water by physical spatial restructuring of its molecules. The modification of an adhesive system by a physical process of molecular rearrangement, done either by the professional researcher or by the manufacturer, opens new possibilities for studies of adhesion stability.

Gonçalves (3) showed that the Grander technology affected the physical properties of Single Bond and Clearfil SE Bond adhesive systems, reducing both the surface tension and contact angle of these adhesive systems. Additionally, Gonçalves (3) observed that both adhesive systems generated a thicker hybrid layer and the Single Bond totaletch adhesive system created a thicker hybrid layer when compared to Clearfil SE Bond self-etch adhesive system, regardless of the substrate and the procedure (control or Grander-modified).

Faissner (15) evaluated all properties of water after the revitalization process (ionic balance, density, conductivity, $\mathrm{pH}$, surface tension, test with boiling alcohol and diagram). He observed that surface tension showed the most significant change, around 10\%. Gonçalves (3) also observed a reduction in surface tension of around $10 \%$. Corroborating with Faissner (15) and Gonçalves (3), this current study showed a significant reduction in surface tension of the water modified by the Grander technology by $4 \%$ (Table 4 ).

However, the Xeno III adhesive did not present a significantly reduced surface tension after the Grander system revitalization process (Table 4). It is possible that it contains a lower percentage of water, or alternatively, that this adhesive system presents a greater molecular complexity. This current result was different from the results found by Gonçalves (3), who observed a significant reduction in surface tension of the Single Bond and Clearfil SE Bond adhesives after the revitalization process by Grander system. The reduced surface tension demonstrates a greater ability of the liquid to wet the substrate and, thereby, improve the adhesiveness and diffusibility (13).

The contact angle varies due to surface topography, surface tension, surface energy of solid substrate and the level of interaction between the liquid and solid (11). Therefore, a smaller contact angle would present a greater surface wettability.

The present study used 20 specimens for each group and 20 measurements for each specimen, generating a very high level of confidence for the results from each group. Additionally, the standardization of the dentin thickness ensured the reliability of results, because the dentin substrate varies based on depth, composition and structure $(3,18-20)$. The roughness of a solid surface influences the results of the contact angle measurement. Thus, the final polishing of the specimens with 4000 sandpaper was performed to reduce the surface roughness (13).

For the contact angle, the current results demonstrate the absence of a significant difference between the procedure 
factor, substrate factor and interaction between the factors. The contact angle measured on the titanium plate represents the characteristics of the diffusivity of liquids, such as surface tension. However, when compared to the bovine dentin substrate, the titanium substrate did not present a significant reduction in the contact angle after the revitalization process by Grander system. Contact angle values vary according to the surface tension of a liquid. The absence of a significant reduction in the surface tension generates an absence of a significant variation in the contact angle. This result is probably due to the physical and chemical characteristics of the Xeno III adhesive system. The self-etch adhesive makes the dentin surface irregular, and the contact angle is more dependent of the surface roughness rather than a reduction of surface tension of the adhesive.

The null hypothesis was rejected for the water, because there was a significant reduction in surface tension of around $4.26 \%$. The null hypothesis was accepted for Xeno III selfetching adhesive because there was no reduction in the surface tension and contact angle properties.

The dental literature is scarce with regards to studies about surface tension and contact angle of current adhesives. Further research should be done that increases the time to freeze the image for self-etching adhesives, because they adhesives may need more time to penetrate the substrate.
Gonçalves (3) used acid etching prior to applying the Single Bond adhesive and applied the primer prior the Clearfil SE Bond. It is possible that the viscous adhesives require more time in contact with the Grander Technology for the revitalization process, due to the lower water content in their formulations (21).

\section{Conclusions}

Based on the current methodology, it can be concluded that:

- A significant reduction in the surface tension occurred in distilled water due to the revitalization process by Grander system when compared to the Distilled water control;

- The Grander technology did not interfere with the surface tension and contact angle physical properties of the Xeno III self-etch adhesive system.

\section{Acknowledgements}

The authors thank the São Paulo State Research Support Foundation - "Fundação de Amparo à Pesquisa do Estado de São Paulo - FAPESP” for financial support (Process No. 06/61896-8).

References 1. Buonocore MG. A simple method, of increasing the adhesion of acrylic filling materials to enamel surfaces. J Dent Res 1955;34:849-53.

2. Marshall GW. Dentin: microstructure and characterization. Quintessence Int 1993;24: 606-17.

3. Gonçalves SEP. Dentina humana e bovina - Estudo comparativo das propriedades físicas e características da hibridização de sistemas adesivos convencionais e grander modificados: análise em MEV [Thesis]. São José dos Campos (SP): Faculdade de Odontologia de São José dos Campos, Universidade Estadual Paulista "Júlio de Mesquita Filho"; 2005.

4. Gonçalves SEP. Dentin bond strength: influence of laser irradiation, acid etching, and hipermeralization. J Clin Laser Med Surg 1999;17:77-85.

5. Hayakawa T. Influence of self-etching primer treatment on the adhesion of resin composite to plished dentin and enamel. Dent Mater 1998;14:99-105.

6. Pashley DH. Permeability of dentin to adhesive agents. Quintessence Int 1993;24: 618-31.

7. Van meerbeck B. The clinical performance of adhesives. J Dent1998;26:1-20.

8. Erickson RL. Surface interactions of dentin adhesive materials. Oper Dent1992;5: 81-94.

9. Nakabayashi N, Sami Y. Bonding to intact dentin. J Dent Res1996;75:1706-15.

10. Nakabayashi N. The promotion of adhesion by the infiltration of monomers into the tooth substrate. J Biomed Mater Res1992;16:265-73.

11. Watanabe I, Nakabayashi N, Pashley DH. Bonding to ground dentin by Phenil-P self-etching primer. J Dent Res 1994;73:1212-20.

12. Won Suck OH, Shen C, Alegre B, Anusavice KJ. Wetting characteristic of ceramic to water and adhesive resin. J Prosthet Dent 2002;88:616-21.

13. Toledano M, Osorio R, de Leonardi G, Rosales-Leal Jl, Ceballos L, Cabrerizo-Vilchez MA. Influence of self-etching primer on the resin adhesion to enamel and dentin. Am J Dent $2001 ; 14: 205-10$.

14. Zuanon ACC, Pansani CA, Cilense M. Estudo comparativo in vitro entre dois selantes fotopolimerizáveis com e sem carga, quanto à umectabilidade e penetração no esmalte de dentes decíduos, após diferentes tempos de condicionamento ácido. Rev ABO Nac $2001 ; 9: 118-23$ 
15. Faissner K. Physical and physical-chemical data in the application of revitalized and nonrevitalized water and the use of Grander water revitalization in industry. [Acess in: 30 March 2000]. Available at: http://www.grander-tecnologie.com/en/wissenschaft-forschung/ DiplomarbeitUniGrass.php.

16. Tonami K. Effect of storage on tensile strength of bovine dentin. [Abstract 2161] J Dent Res 1996;75:288.

17. Gordan V. Evaluation of acid primers in microleakage of class 5 composite resin restoration. Oper Dent 1998;23:244-9.

18. Wang $Y$, Spencer $P$, Yao X, Brenda B. Effect of solvent content on resin hybridization in wet dentin bonding. J Biomed Mater Res A 2007;82:975-83.

19. Tay FR, Pashley DH. Aggressiveness of contemporary self-etching system. I: depth of penetration beyond dentin smear layers. Dent Mater 2001;1 7:296-308.

20. Pashley DhH, Tay FR, Breschi L, Tjäderhane L, Carvalho RmM, Carrilho M et al. State of the art etch-and-rinse adhesives. Dent Mater 2011;27:1-16.

21. Malacarne-Zanon J, Pashley DH, Agee KA, Foulger S, Alves MC, Breschi L et al. Effects of ethanol addition on the water sorption/solubility and percent conversion of comonomers in model dental adhesives. Dent Mater 2009;25:1275-84. 